\title{
Comparison of local fruit flies attractant with imported attractants (Methyl Eugenol \& Cue Lure) in guava, peach and bitter gourd orchards in Khyber Pakhtunkhwa
}

\author{
Muhammad Qasim Kakar ${ }^{*}$, Farman Ullah², Bashir Ahmad ${ }^{2}$, Hayat Zada ${ }^{2}$, \\ Arif $\mathrm{Shah}^{3}$, Toheed Iqbal ${ }^{4}$ and Sajjad Ahmad \\ 1. Department of Agriculture Extension Balochistan, Pakistan \\ 2. Department of Plant Protection, University of Agriculture Peshawar, Pakistan \\ 3. Balochistan Agriculture College Quetta, Pakistan \\ 4. Department of Entomology, University of Agriculture Peshawar, Pakistan \\ *Corresponding author's email: qasimkakar@aup.edu.pk
}

Citation

Muhammad Qasim Kakar, Farman Ullah, Bashir Ahmad, Hayat Zada, Arif Shah, Toheed Iqbal and Sajjad Ahmad. Comparison of local fruit flies attractant with imported attractants (Methyl Eugenol \& Cue Lure) in guava, peach and bitter gourd orchards in Khyber Pakhtunkhwa. Pure and Applied Biology. Vol. 5, Issue 4, pp695-713. http://dx.doi.org/10.19045/bspab.2016.50088

\begin{tabular}{llll}
\hline \hline Received: 26/05/2016 & Revised: 02/06/2016 & Accepted: 20/06/2016 & Online First: 09/07/2016 \\
\hline
\end{tabular}

\section{Abstract}

Studies were carried out for comparison of local fruit fly attractant with imported attractants, in Khyber Pakhtunkhwa during 2010 and 2011. The trials were conducted in three different localities in different orchards i.e Swat (Peach orchards), Charsada (Bitter gourd) and Kohat (Guava orchards). The experiment was consisted of different attractants i.e. Methyl Eugenol (M.E), Cue Lure (C.L) and protein based product locally developed (PPr-Product) for efficient management of Tephritid species in the field in modified McPhill traps. The trials were laid out in randomized complete block design replicated three times. Findings showed that significant variation was recorded for the captured of fruit flies among different attractants and observational dates in guava, peach and bitter gourd orchards. Methyl eugenol trapped more fruit flies as compared PPr-Product and C.L trap in Guava and Peach orchards whereas higher number of fruit flies was captured by PPr-Product as compared to both C.L and M.E traps in bitter gourd orchards. Higher capture of B. zonata and B. dorsalis in guava and peach orchards was recorded by M.E whereas C.L attracted more B. cucuribitae as compared to M.E traps for Peach, Guava and Bitter gourd orchards. More numbers of B. zonata and B. dorsalis captured by PPr-Product in Bitter gourd. The highest trapped fruit flies in Peach orchards were recorded in mid September. For Bitter gourd orchards, the fruit fly capture increased from March to $1^{\text {st }}$ September and the highest peak of its species were in September. For Guava orchards, the fruit fly trapped population and its species increased till $1^{\text {st }} \mathrm{July}$ and then decreased thereafter. The PPr-Product traps were found more effective against all three types of female adults flies whereas M.E traps captured more male adults of B. Zonata and B. dorsalis while C.L captured more male adults of B. cucurbitae in Peach, Bitter gourd and Guava orchards. The highest capture of female adults of the three species was obtained by PPr-Product in Guava and Peach orchards.

Keywords: PPr-Product; $B$. zonata; Localities; $B$. cucurbitae 


\section{Introduction}

Fruit flies (Diptera: Tephritidae) are among the most economically important pests attacking fruits worldwide and usually attack commercial fruits [1]. They are found in almost everywhere in the world with hosts plants [2]. They damaged the fruits and losses to fruits throughout the world, known as major pest of horticultural industries [3]. They have great economic importance in Pakistan due to their heavy losses to fruits at the farm level with estimated loss of 200 million US dollar annually [4]. The losses caused to fruits by fruit flies varied according to species and the host fruit plant species. Oriental fruit fly (Bactrocera dorsalis) is the most serious pest and caused losses $5-100 \%$ to various fruits [5] while, in guava fruit Bactrocera correcta caused 60-80\% losses [6]. The peach fruit fly (B. zonta) is another devastating pest species, found most abundantly in most of the ecological regions of Pakistan and causing losses from 3-100 \% in different fruits. The Ber fruit fly (Carpomya vesuviana) may cause 90-100\% damage to Ber fruit [7].

Many conventional and modern techniques of pest control have been tested to avoid the losses caused by fruit flies in the world [8]. Protein baits with insecticides have been one of the most popular and effective for control of tephritids fruit flies [9]. The use of cover insecticide sprays against fruit flies is widespread and increasing [4]. Enzymatic protein hydrolysate baits were also used for control of oriental fruit fly [10].

The use of attractants is the most important components of fruit fly detection, monitoring, control and eradication programs throughout the world [11]. Various synthetic and natural semiochemicals provide the means to detect the occurrence of flies in a region. Traps baited with attractants are also used to monitor fruit fly populations over time. It is mixed with various insecticides to control flies and more powerful attractants are the basis for technologies such as male annihilation. The status of semio-chemical attractants for tephritid fruit flies has recently been reviewed by [12]. While these powerful techniques have been used for many years, hydrolysed protein baits are known to capture males and females [13]; a female pheromone formulation has been developed. However, in some instances, the use of male lures and protein baits are being fostered for the control of fruit flies. These control measures are not practiced in integrated manner.

Keeping in view the havoc created effect by fruit fly, it is imperative to develop a low cost attractants for the control of both male and female of fruit fly species, comparison of local attractants with imported attractants.

\section{Material and methods}

Studies were carried out to compare local fruit fly attractant with imported attractant For this purpose different fruits/vegetables were surveyed through different attractant traps for efficacy of attractants and intensity of fruit fly population for the species compositions of the Tephritid pests in the target area. Female of the fruit flies are attracted to protein source for their body development particularly virgin females and therefore it was used as bait or food attractants. Female required more protein for the development of eggs than male. For the development of local attractant protein based chemicals (attracting both sexes) was tested in modified Mcphil fruit fly traps. Protein bait was prepared using protein source. This bait was compared with imported attractants in replicated field trials. These locally formulated protein bait (PPrProduct) was compared with the currently used (imported) attractants Methyl eugenol (M.E) and Cue lure (C.L) in three different locations. The trails were conducted in three different localities in different orchards i.e 
Swat (Peach orchards), Charsada (Bitter gourd) and Kohat (Guava orchards). The experiments were consisted of different attractants i.e. Methyl Eugenol (M.E), Cue Lure (C.L) and Protein based product locally developed (PPr-Product). A mixture of attractant, sugar and insecticide in the ratio of 85:10:5 was prepared for each trap. Six traps acre-1 was installed (two per treatment) in each experimental orchard and vegetable fields. After 15 days traps were examined and trapped fruit flies were counted for relative abundance and sex ratio determination. Traps were washed and replenished with fresh lure mixture at monthly intervals and was carried on till the fruit/vegetable last picking. The trials were laid out in randomized complete block design replicated three times.

Data were recorded on the following parameters for two years.

\section{Number of fruit flies}

The numbers of fruit flies were recorded by counting number of flies captured in two traps of each treatment and then averaged.

\section{Sex ratio}

The captured flies in each trap was carefully examined for sex ratio determination by dividing male and female numbers on total number of flies.

\section{Species determination}

Species were determined by studying the morphological features/characters of captured flies. The collected specimen of fruit flies was identified with the help of taxonomical keys followed [13] Mahmood (2002) and Drew RAI (1989a). [14]

\section{Protein Bait Preparation (Yeast autolysate)}

Baking Yeast was obtained from local market and bait (in one liter water) was prepared by adding100 g dry yeast , $100 \mathrm{~g}$ sugar (first dissolved in some water), few grains of NPK up to 5 grams (first dissolve in water) and at last added $5 \mathrm{ml}$ multivitamins (lysovit) with minerals (dissolve in Water). Leave it for 12 and 40 hours in summer winter, respectively. This process causes a degree of yeast cell autolysis and a release of cell contents. In a separate beaker took some water, added 10 $\mathrm{ml}$ mixture of different oil (with fatty acids of 4-14 carbon atoms and their mono-, diand tri-glyceride esters) and add a pinch of Aerial- detergent and then added some Coke or Pepsi Cola (just a little). Add the above solution to the yeast solution.

Leave it overnight and heat the aqueous suspension of live yeast cells to $20^{\circ} \mathrm{C}$ for 36 hours or to $60^{\circ} \mathrm{C}$ for $6 \mathrm{hrs}$. Keep stirring during the heating process (using magnetic stirrer) to separate the shells of the yeast cells from the liquid, to evaporate said liquid and to recover the yeast autolysate. Keep Adding warm water and leave it to get cool. Sodium benzoate (as a preserving agent) was then added at a rate of $2 \%$ and the liquid was allowed to settle down. Glycerin was added at the rate of $10 \%$ to increase its persistency.

\section{Statistical analysis}

Data were analyzed according to the procedure appropriate for randomize complete block design. The significant means were compared by using least significant difference test [15].

\section{Results}

Number of fruit flies captured by different attractants in guava orchard

Data on number of fruit flies attracted by various attractants in Guava orchard are reported in table 1. Different attractants and observational dates showed significant differences in attracting fruit flies in guava orchards during both the years. The effect of year was found non-significant. Interaction between attractants and observation dates was also found significant for number of fruit flies in Guava. Mean values of the data indicated that M.E captured more fruit flies (46.1) followed by PPr-Product (27.7) 
whereas smaller numbers of flies (9.3) were captured by C.L trap. (Fig.1).

Table 1. Number of fruit flies (overall), B. zonata, B. dorsalis and B. cucurbitae captured by different attractants from March to December during 2010 and 2011 in guava at Kohat District

\begin{tabular}{|c|c|c|c|c|c|}
\hline & Treatments & $\begin{array}{l}\text { fruit } \\
\text { flies }\end{array}$ & $(B . z)$ & $(B . d)$ & $(B . c)$ \\
\hline \multirow[t]{4}{*}{ Attractants (A) } & M.E & $46.1 \mathrm{a}$ & $33.9 \mathrm{a}$ & $11.8 \mathrm{a}$ & $0.0 \mathrm{c}$ \\
\hline & C.Lure & $9.3 \mathrm{c}$ & $0.0 \mathrm{c}$ & $0.0 \mathrm{c}$ & $9.0 \mathrm{a}$ \\
\hline & PPr-Prod & $27.7 \mathrm{~b}$ & $13.8 \mathrm{~b}$ & $6.8 \mathrm{~b}$ & $7.0 \mathrm{~b}$ \\
\hline & LSD & 3.03 & 2.66 & 1.71 & 1.53 \\
\hline \multirow[t]{21}{*}{ Dates } & $1^{\text {st }}$ March & $7.7 \mathrm{~lm}$ & $4.0 \mathrm{kl}$ & $1.7 \mathrm{~g}$ & $1.8 \mathrm{ij}$ \\
\hline & $15^{\text {th }}$ March & $7.1 \mathrm{mn}$ & $3.8 \mathrm{kl}$ & $1.7 \mathrm{~g}$ & $1.3 \mathrm{ij}$ \\
\hline & $1^{\text {st }}$ April & $15.1 \mathrm{j}$ & $9.1 \mathrm{hi}$ & $3.9 \mathrm{ef}$ & $2.2 \mathrm{ij}$ \\
\hline & $15^{\text {th }}$ April & $26.6 \mathrm{gh}$ & $14.4 \mathrm{fg}$ & $6.7 \mathrm{~cd}$ & $4.9 \mathrm{ef}$ \\
\hline & $1^{\text {st }}$ May & $25.3 \mathrm{~h}$ & $13.7 \mathrm{~g}$ & $6.7 \mathrm{~cd}$ & $4.6 \mathrm{fg}$ \\
\hline & $15^{\text {th }}$ May & $31.6 \mathrm{f}$ & $17.7 \mathrm{e}$ & $6.7 \mathrm{~cd}$ & $6.6 \mathrm{c}-\mathrm{e}$ \\
\hline & $1^{\text {st }}$ June & $42.8 \mathrm{~d}$ & $24.6 \mathrm{~d}$ & $11.0 \mathrm{~b}$ & $6.7 \mathrm{c}-\mathrm{e}$ \\
\hline & $15^{\text {th }}$ June & $61.4 \mathrm{~b}$ & $40.4 \mathrm{~b}$ & $12.4 \mathrm{~b}$ & $8.3 \mathrm{c}$ \\
\hline & $1^{\text {st }}$ July & $79.4 \mathrm{a}$ & $43.8 \mathrm{a}$ & $16.7 \mathrm{a}$ & $18.3 \mathrm{a}$ \\
\hline & $15^{\text {th }}$ July & $52.7 \mathrm{c}$ & $27.9 \mathrm{c}$ & $12.0 \mathrm{~b}$ & $12.6 \mathrm{~b}$ \\
\hline & $1^{\text {st }}$ August & $43.3 \mathrm{~d}$ & $25.3 \mathrm{~cd}$ & $10.5 \mathrm{~b}$ & $7.4 \mathrm{~cd}$ \\
\hline & $15^{\text {th }}$ August & $35.8 \mathrm{e}$ & $22.2 \mathrm{~d}$ & $7.9 \mathrm{c}$ & $5.7 \mathrm{~d}-\mathrm{f}$ \\
\hline & $1^{\text {st }}$ September & $29.6 \mathrm{fg}$ & $17.3 \mathrm{ef}$ & $7.0 \mathrm{c}$ & $5.2 \mathrm{ef}$ \\
\hline & $15^{\text {th }}$ September & $24.1 \mathrm{~h}$ & $13.6 \mathrm{~g}$ & $4.8 \mathrm{de}$ & $5.5 \mathrm{ef}$ \\
\hline & $1^{\text {st }}$ October & $13.8 \mathrm{jk}$ & $7.7 \mathrm{ij}$ & $2.6 \mathrm{fg}$ & $2.9 \mathrm{~g}-\mathrm{i}$ \\
\hline & $15^{\text {th }}$ October & $20.1 \mathrm{i}$ & $11.8 \mathrm{gh}$ & $4.1 \mathrm{ef}$ & $4.2 \mathrm{f}-\mathrm{h}$ \\
\hline & $1^{\text {st }}$ November & $14.9 \mathrm{j}$ & $9.3 \mathrm{hi}$ & $3.0 \mathrm{e}-\mathrm{g}$ & $2.6 \mathrm{~h}-\mathrm{j}$ \\
\hline & $15^{\text {th }}$ November & 10.9-kl & $5.5 \mathrm{jk}$ & $2.6 \mathrm{fg}$ & $2.8 \mathrm{~g}-\mathrm{j}$ \\
\hline & $1^{\text {st }}$ December & $7.41-n$ & $4.3 \mathrm{kl}$ & $1.5 \mathrm{~g}$ & $1.6 \mathrm{ij}$ \\
\hline & $15^{\text {th }}$ December & $3.9 \mathrm{n}$ & 1.91 & $1.1 \mathrm{~g}$ & $1.0 \mathrm{j}$ \\
\hline & LSD & 3.587 & 3.140 & 2.018 & 1.806 \\
\hline \multirow[t]{3}{*}{ Year } & 2011 & 27.9 & 16.2 & 6.1 & 5.2 \\
\hline & 2012 & 27.5 & 15.6 & 6.3 & 5.4 \\
\hline & Significance & Ns & $\mathrm{Ns}$ & $\mathrm{Ns}$ & Ns \\
\hline Interaction & $A \times D$ & 0.00 & 0.00 & 0.00 & 0.00 \\
\hline
\end{tabular}

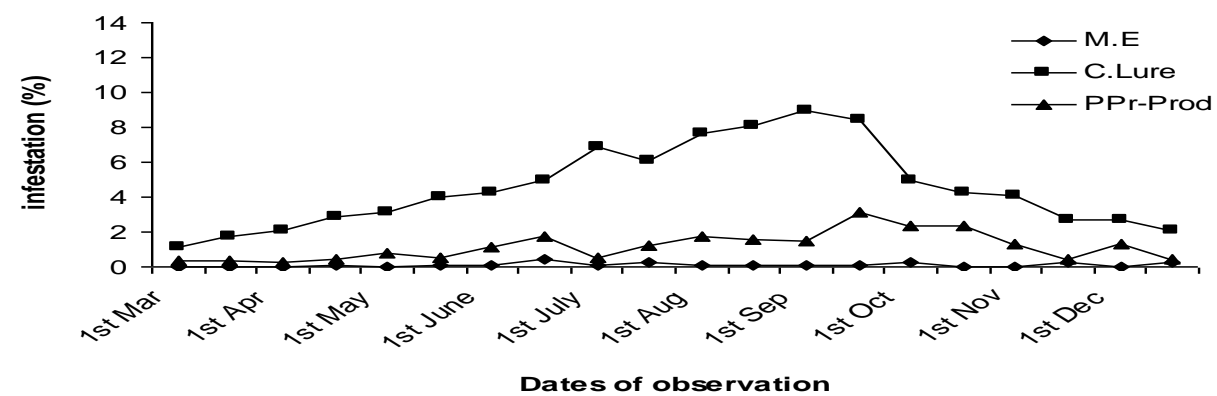

Figure 1. Interaction of attractant and dates for number of fruit flies (overall) in guava orchard at Kohat during 2010 and 2011 


\section{Number of Bactrocera zonata (Guava)}

Number of Bactrocera zonata was significantly altered by attractants and various observational dates in guava during both the years (Table 1). Number of $B$. zonata was found similar in both the year. The interaction between attractants and dates were also found significant for number of B. zonata in Guava. M.E had the highest captured of B. zonata (33.9) followed by PPr-Product (13.8), whereas a single species of $B$. zonata was not trapped in C.L traps. Number of $B$. zonata increased from $1^{\text {st }}$ march to end of June where the number of B. zonata were in its peak and from July to mid of December its population decreased drastically. The highest captured of $B$. zonata (43.8) was recorded in early July followed by $15^{\text {th }}$ June (40.4) whereas, least captured was noted in the months November, December and March (5.5, 4.3 and 1.9 , respectively). Interaction between attractants and dates of observation revealed that M.E trapped more B. zonata in month of July as compared to C. L (Fig.2).

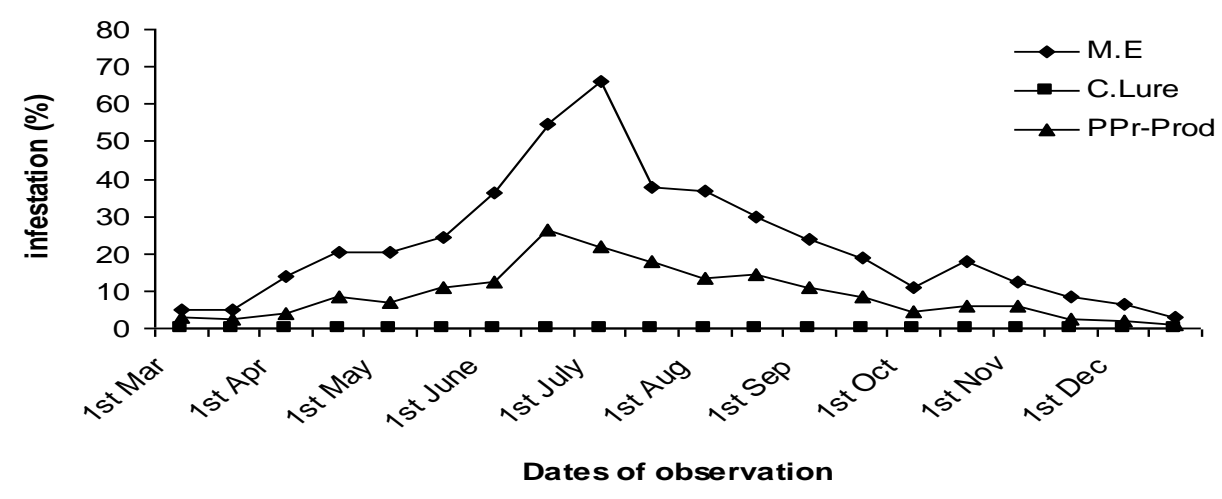

Figure 2. Interaction of attractant and dates for Bactrocera zonata in guava orchard at Kohat during 2010 and 2011

\section{Number of Bactrocera dorsalais (Guava)}

Data regarding number of $B$. dorsalis attracted to different attractants in Guava are presented in table 1. Statistical analysis of the data showed that attractants were found significantly different in capturing fruit flies. Likewise, number of fruit flies varied among different dates. Year as source of variance was found not significant. The interaction between attractants and dates remained significant. Two year averaged data revealed that M.E. traps had the highest capture of $B$. dorsalis (11.8) followed by PPr-Product (6.8), whereas not a single capture of $B$. dorsalis was recorded in $\mathrm{C}$. L traps. The capture of $B$. dorsalis was increased from march to early July and there after it declined till mid December and hence the highest capture of $B$. dorsalis were recorded in traps observed on $1^{\text {st }}$ July (16.7) which was similar to the capture in months of early and mid June, mid July and early August with values $11,12.4,12,10.5$, respectively. These were followed by mid August, early September, mid April and month of May (7.9, 7.0, 6.7 and 6.7, respectively) whereas the least $B$. dorsalis (1.1) were captured in mid December which was at par with early December, November and month of March (3.0, 2.6, 1.7, 1.7, respectively). Interaction between attractants and dates of observation showed that $B$. dorsalis capture increased from March to month of July for M. E as compared to C. L (Fig. 3). 


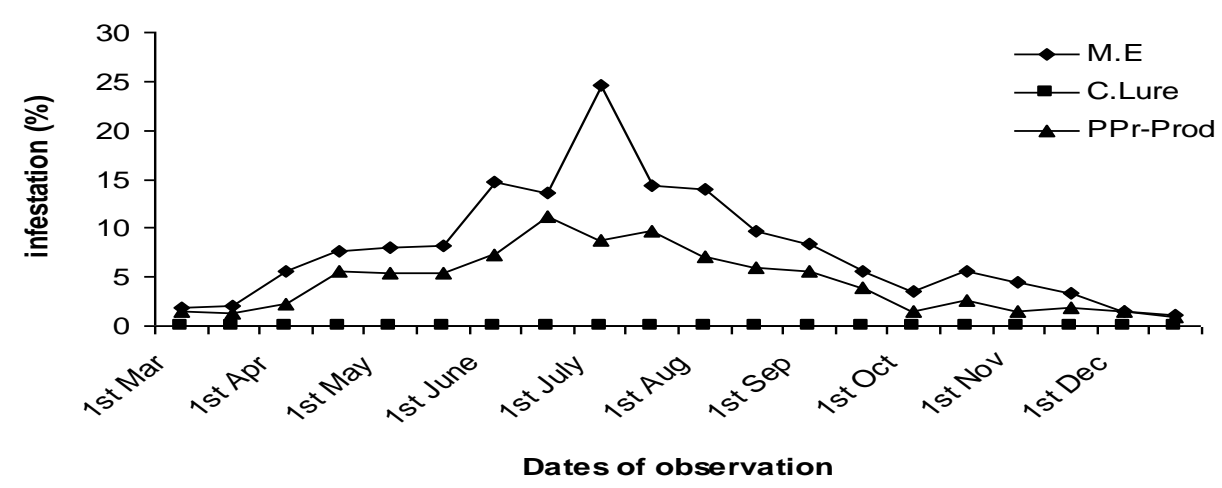

Figure 3. Interaction of attractant and dates for Bactrocera dorsalis in guava orchard at Kohat during 2010 and 2011

Number of Bactrocera cucuribitae (Guava)

Data on number of Bactrocera cucuribitae attracted to different attractants are shown in table 2. Statistical analysis of the data showed that attractants and observational dates were found significantly different in capturing fruit flies. There were no significant differences in number $B$. cucuribitae during both the years. The interaction between attractants and dates was remained significant for number of $B$. cucuribitae. It was found from the two year averaged data that C.L had the maximum capture of B. cucuribitae (9) followed by PPr-Product (7), whereas there was not even a single capture of $B$. cucuribitae was recorded in M.E traps. The number of $B$. cucuribitae captured in traps was increased from March to mid July and then it was declined from July to December. The higher number of $B$. cucuribitae were trapped in early July (18.3) followed by mid July (12.6) whereas the least number of $B$. cucuribitae(1) was captured in mid December which was statistically similar to the capture of flies in months of October, November and March. Interaction between attractants and dates of observation indicated that more number of B. cucurbitae were captured by C. L in month of July as compared to M. E (Fig. 4)

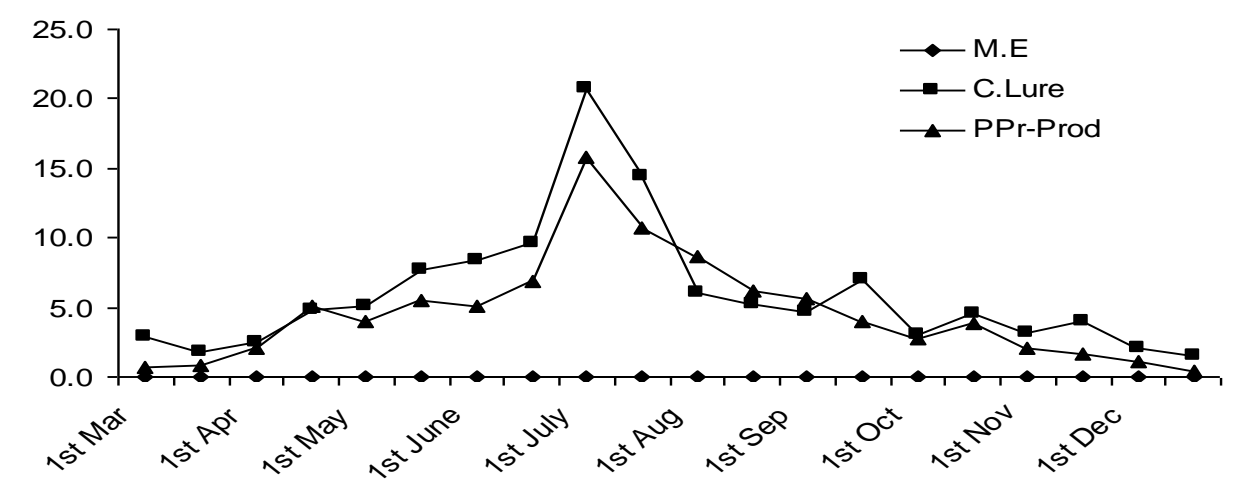

Figure 4. Interaction of attractant and dates for Bactrocera cucurbitae in guava orchard at Kohat during 2010 and 2011 
Number of fruit flies captured by different attractants in Peach orchard Data recoded on number of fruit flies attracted by attractants in Peach are reported in table 2. Different attractants and dates showed significant differences in attracting fruit flies in Peach orchard during both the years. The effect of year was found not significant. Interaction between attractants and observation dates were also found significant for number of fruit flies in Peach. Mean values of two year averaged data indicated that M.E trapped higher number of fruit flies (30.4) followed by PPr-Product (22.0) whereas lower number of fruit flies (6.9) was recorded in C.L trap. Higher fruit fly were trapped in mid September (46.7) followed by early September (44.7). The lower numbers of fruit flies (3) were trapped in the month of March followed by April with 4.6 and 5.3 fruit flies infestation. Interaction between attractants and dates of observation indicated that more number of fruit flies were captured by C.L in month of July as compared to M. E (Fig.5).

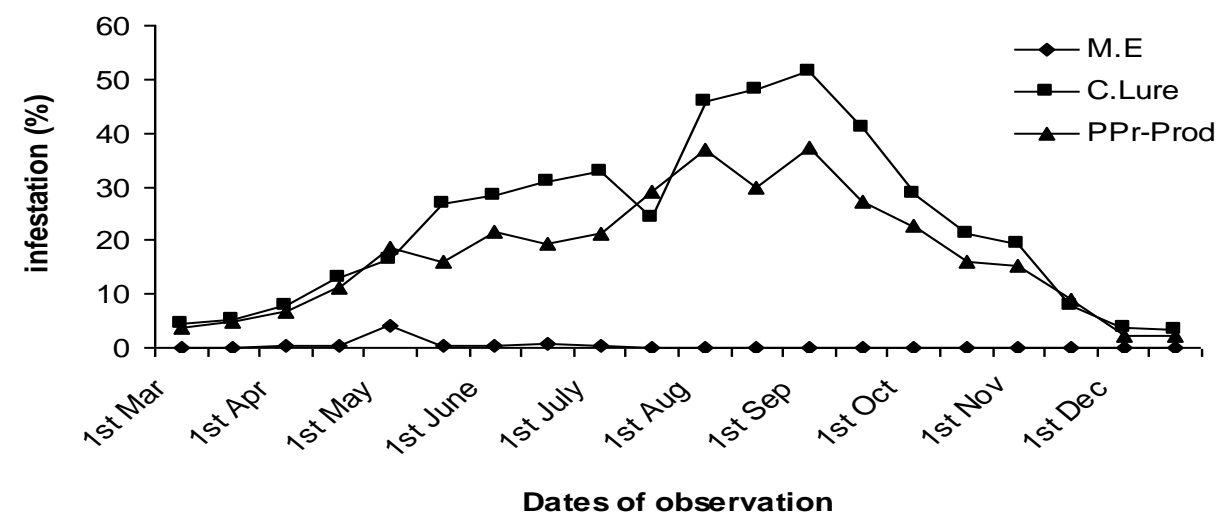

Figure 5. Interaction of attractant and dates for number of fruit flies (overall) in peach orchard at Swat during 2010 and 2011

Number of Bactrocera zonata (Peach)

Number of Bactrocera zonata was significantly influenced by different attractants and various observational dates in Peach during both the years (Table 2). Number of $B$. zonata was non significant in both the years. The interaction between attractants and dates were also found significant for number of $B$. zonata in Peach orchard. Higher number of $B$. zonata (22.9) was trapped by M. E followed by PPrProduct (16.0), whereas there was not a single capture of $B$. zonata in C. L traps. Number of $B$. zonata increased from $1^{\text {st }}$ march to end of September where the number of $B$. zonata were in its peak (30.2 and 29.9) followed by mid August and $1^{\text {st }}$ October (25.9 and 23.7, respectively) and after that till mid of December its population was decreased drastically and thus lesser $B$. zonata were trapped in month of December (3 and 3.4) which was statistically non significant with the fruit flies captured in months of march, April and early days of May. Interaction between attractants and dates of observation revealed that M.E trapped more fruit flies in month of July as compared to C. L (Fig. 6) 
Table 2. Number of fruit flies (overall), B. zonata, B. dorsalis and B. cucurbitae captured by different attractants from March to December during 2010 and 2011 in peach orchards at Swat

\begin{tabular}{|c|c|c|c|c|c|}
\hline & Treatments & fruit flies & $(B . z)$ & $(B . d)$ & (B.c) \\
\hline \multirow{4}{*}{ Attractants (A) } & M.E & $30.4 \mathrm{a}$ & $22.9 \mathrm{a}$ & $7.7 \mathrm{a}$ & $0.2 \mathrm{c}$ \\
\hline & C.Lure & $6.9 \mathrm{c}$ & $0.0 \mathrm{c}$ & $0.0 \mathrm{c}$ & $6.8 \mathrm{a}$ \\
\hline & PPr-Prod & $22.0 \mathrm{~b}$ & $16.0 \mathrm{~b}$ & $4.3 \mathrm{~b}$ & $1.8 \mathrm{~b}$ \\
\hline & LSD & 1.40 & 2.95 & 1.60 & 1.24 \\
\hline \multirow[t]{21}{*}{ Dates } & $1^{\text {st }}$ March & $3.0 \mathrm{~m}$ & $1.7 \mathrm{~h}$ & $0.6 \mathrm{~h}$ & $0.7 \mathrm{~h}$ \\
\hline & $15^{\text {th }}$ March & $4.6 \mathrm{~lm}$ & $2.7 \mathrm{~h}$ & $0.9 \mathrm{gh}$ & $1.1 \mathrm{gh}$ \\
\hline & $1^{\text {st }}$ April & 5.31 & $3.1 \mathrm{~h}$ & $1.1 \mathrm{gh}$ & $1.2 \mathrm{gh}$ \\
\hline & $15^{\text {th }}$ April & $6.2 \mathrm{kl}$ & $3.4 \mathrm{~h}$ & $1.9 \mathrm{f}-\mathrm{h}$ & $1.7 \mathrm{f}-\mathrm{h}$ \\
\hline & $1^{\text {st }}$ May & $8.2 \mathrm{j}$ & $4.6 \mathrm{~h}$ & $1.7 \mathrm{f}-\mathrm{h}$ & $1.9 \mathrm{e}-\mathrm{h}$ \\
\hline & $15^{\text {th }}$ May & $12.7 \mathrm{i}$ & $8.2 \mathrm{~g}$ & $2.0 \mathrm{f}-\mathrm{h}$ & $2.3 \mathrm{~d}-\mathrm{g}$ \\
\hline & $1^{\text {st }}$ June & $17.6 \mathrm{~h}$ & $12.2 \mathrm{f}$ & $2.6 \mathrm{fg}$ & $2.7 c-f$ \\
\hline & $15^{\text {th }}$ June & $20.2 \mathrm{~g}$ & $13.1 \mathrm{f}$ & 3.4 ef & $3.6 \mathrm{~b}-\mathrm{d}$ \\
\hline & $1^{\text {st }}$ July & $25.8 \mathrm{f}$ & $17.3 \mathrm{e}$ & $5.2 \mathrm{de}$ & $3.8 \mathrm{bc}$ \\
\hline & $15^{\text {th }}$ July & $27.3 \mathrm{f}$ & $18.1 \mathrm{de}$ & $6.8 \mathrm{~cd}$ & $3.8 \mathrm{bc}$ \\
\hline & $1^{\text {st }}$ August & $31.4 \mathrm{e}$ & $21.3 \mathrm{~cd}$ & $5.3 \mathrm{~d}$ & $4.8 \mathrm{ab}$ \\
\hline & $15^{\text {th }}$ August & $37.7 \mathrm{c}$ & $25.9 \mathrm{~b}$ & $6.8 \mathrm{cb}$ & $4.9 \mathrm{ab}$ \\
\hline & $1^{\text {st }}$ September & $44.7 \mathrm{~b}$ & $30.2 \mathrm{a}$ & $9.2 \mathrm{ab}$ & $5.3 \mathrm{a}$ \\
\hline & $15^{\text {th }}$ September & $46.7 \mathrm{a}$ & $29.9 \mathrm{a}$ & $10.8 \mathrm{a}$ & $5.8 \mathrm{a}$ \\
\hline & $1^{\text {st }}$ October & $35.5 \mathrm{~d}$ & $23.7 \mathrm{bc}$ & $7.9 \mathrm{bc}$ & $3.8 \mathrm{bc}$ \\
\hline & $15^{\text {th }}$ October & $27.0 \mathrm{f}$ & $17.6 \mathrm{e}$ & $6.2 \mathrm{~cd}$ & $3.3 \mathrm{c}-\mathrm{e}$ \\
\hline & $1^{\text {st }}$ November & $17.8 \mathrm{~h}$ & $11.9 \mathrm{f}$ & $3.2 \mathrm{f}$ & $2.7 \mathrm{c}-\mathrm{f}$ \\
\hline & $15^{\text {th }}$ November & $11.3 \mathrm{i}$ & $8.1 \mathrm{~g}$ & $1.6 \mathrm{f}-\mathrm{h}$ & $1.7 \mathrm{fg}$ \\
\hline & $1^{\text {st }}$ December & $7.1 \mathrm{jk}$ & $3.4 \mathrm{~h}$ & $1.6 \mathrm{f}-\mathrm{h}$ & $2.0 \mathrm{e}-\mathrm{h}$ \\
\hline & $15^{\text {th }}$ December & 5.41 & $3.0 \mathrm{~h}$ & $1.1 \mathrm{gh}$ & $1.4 \mathrm{f}-\mathrm{h}$ \\
\hline & LSD & 1.652 & 3.484 & 1.893 & 1.468 \\
\hline \multirow[t]{3}{*}{ Year } & 2011 & 19.1 & 12.5 & \begin{tabular}{|l|}
4.1 \\
\end{tabular} & 2.5 \\
\hline & 2012 & 20.5 & 13.4 & 3.9 & 3.3 \\
\hline & Significance & Ns & Ns & Ns & Ns \\
\hline Interaction & $A \times D$ & 0.00 & 0.00 & 0.00 & 0.00 \\
\hline
\end{tabular}

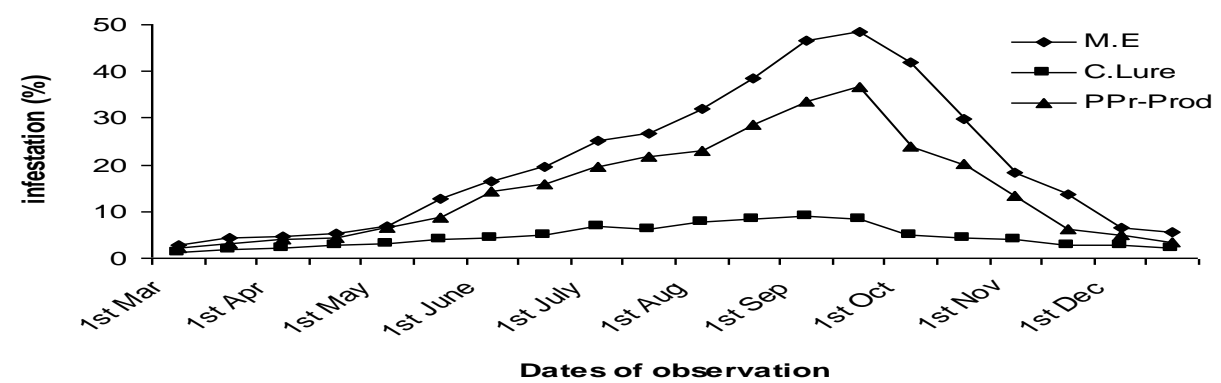

Figure 6. Interaction of attractant and dates for number Bactrocera zonata in peach orchard at Swat during 2010 and 2011 
Number of Bactrocera dorsalis (Peach)

Various attractants were found significantly different in trapping fruit flies. Likewise, number of fruit flies varied among different dates. Year as source of variance was found not significant. The interaction between attractants and dates were also significant (Table 2). Two year averaged data showed that M. E had the maximum capture of $B$. dorsalis (7.7) followed by PPr-Product (4.3), whereas C. L traps could not capture a single $B$. dorsalis fly. The capture of $B$. dorsalis increased from march to $15^{\text {th }}$ September and after it decline till mid of December and hence higher number of $B$. dorsalis were recorded in traps observed on $15^{\text {th }}$ September followed by $1^{\text {st }}$ September, whereas it was lowered in trap recorded on March, November and December. Interaction between attractants and dates of observation revealed that M.E trapped more B. dorsalis than C. L in month of July (Fig. 7).

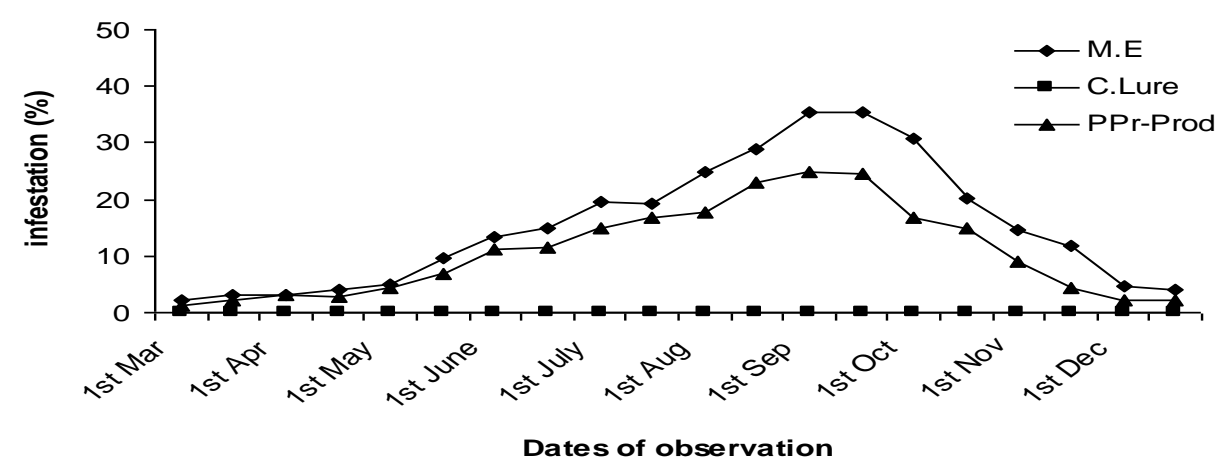

Figure 7. Interaction of attractant and dates for Bactrocera dorsalis in peach orchard at Swat during 2010 and 2011

\section{Number of Bactrocera cucuribitae (Peach)}

Data recorded on number of B.cucuribitae attracted to different attractants are shown in table 2. Statistical analysis of the data showed that the number of B. cucuribitae was significantly influenced by different attractants and observational dates. Year as source of variance was found not significant. The interaction between attractants and dates was remained significant for number of B. cucuribitae. It was found from the two year averaged data that C.L had the highest number of $B$. cucuribitae (6.8) followed by PPr-Product (1.8), whereas less number of B. cucuribitae (0.2) was captured by M.E traps. The number of $B$. cucuribitae increased from March to mid September and then it was declined from $1^{\text {st }}$ October till the end of December. The highest number of $B$. cucuribitae (5.8) was captured in mid September which was similar to the flies captured in early Septmber and month of August. These were followed by both $1^{\text {st }}$ October and $1^{\text {st }}$ July (3.8) which were at par with $B$. cucribitae trapped in months of mid June and July, and month of October. The least number of B. cucuribitae was captured in March (0.7) which were similar to flies captured in months of December, April, and May. Interaction between attractants and dates of observation showed that $B$. ccuribitae capture increased from March to month of July for C. L as compared to M.E (Fig.8). 


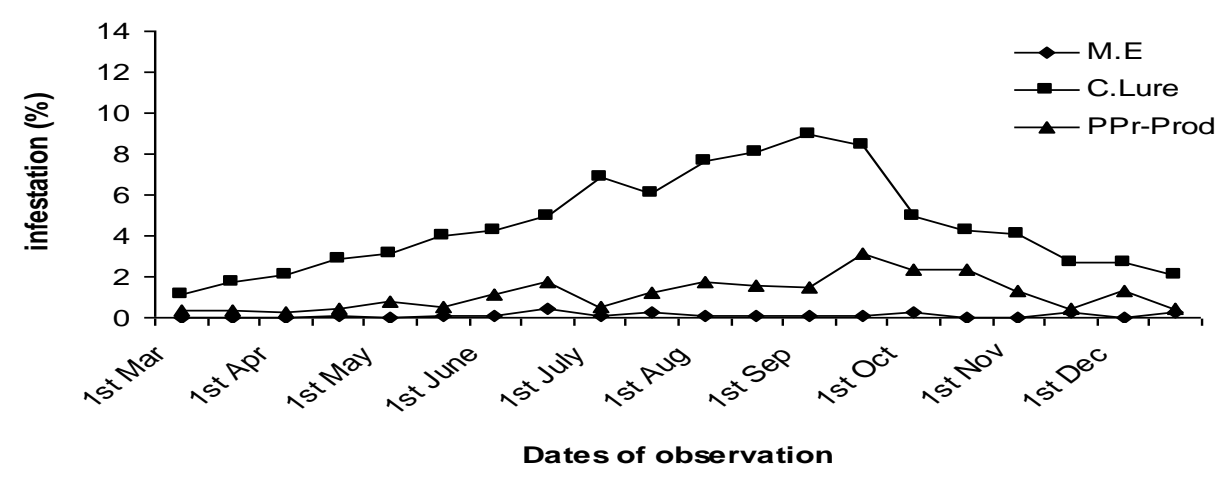

Figure 8. Interaction of attractant and dates for number Bactrocera cucurbitae in peach orchard at Swat during 2010 and 2011

Number of fruit flies captured by different attractants in Bitter gourd filed Data regarding number of fruit flies attracted by various attractants in Bitter gourd are reported in Table 3. Different attractants and observational dates showed significant differences in attracting fruit flies in Bitter gourd during both the years. The effect of year was found non significant. Interaction between attractants and observation dates remained significant for number of fruit flies. PPr-Product captured more number of fruit flies (36.2) followed by C. L (28.2) whereas lesser number of fruit flies (11.4) was trapped by M. E. More fruit flies (51.5) were captured in mid August which was at par with fruit flies trapped on $1^{\text {st }}$ August, and $1^{\text {st }}$ September followed by mid July (43) which were similar to mid September. The least number of flies (5.3) were trapped in early March which was statistically similar to mid March. Interaction between attractants and dates of observation revealed that PPr-Product trapped more fruit flies in month of September in Bitter gourd orchards followed by C. L and M.E (Fig.9).

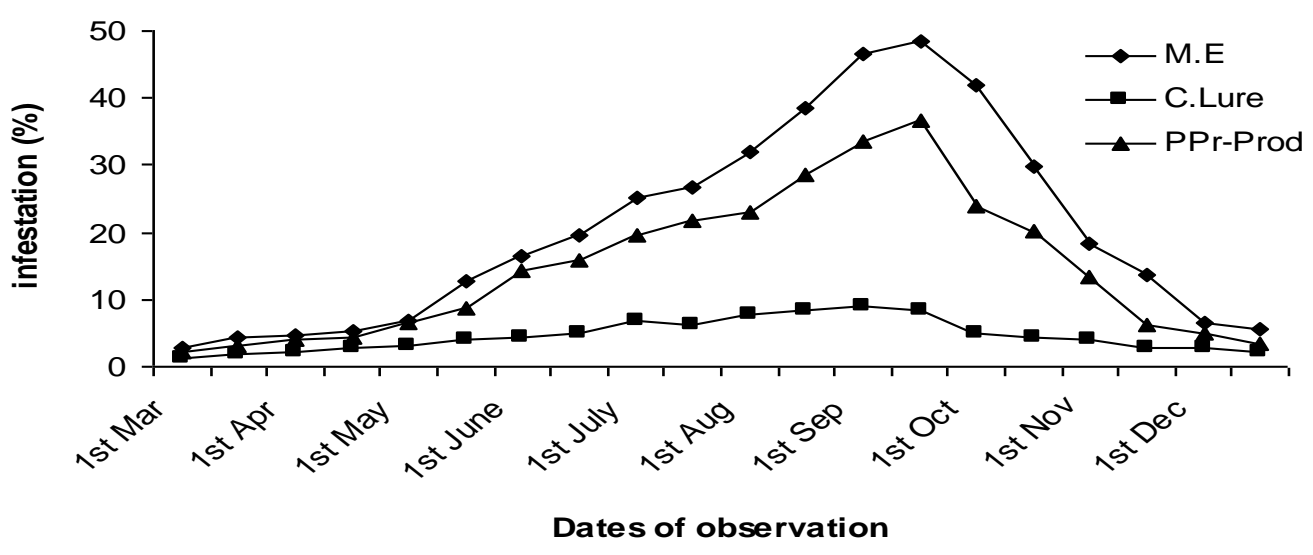

Figure 9. Interaction of attractant and dates for number fruit flies in bitter gourd at Charsada during 2010 and 2011 
Table 3. Number of fruit flies (overall), B. zonata, B. dorsalis and B. cucurbitae captured by different attractants from March to December during 2010 and 2011 in bitter gourd at Charsada

\begin{tabular}{|c|c|c|c|c|c|}
\hline & Treatments & fruit flies & (B.z) & (B.d) & (B.c) \\
\hline \multirow[t]{4}{*}{ Attractants (A) } & M.E & $11.4 \mathrm{c}$ & $8.3 \mathrm{~b}$ & $2.6 \mathrm{~b}$ & $0.5 \mathrm{c}$ \\
\hline & C.Lure & $28.2 \mathrm{~b}$ & $0.8 \mathrm{c}$ & $0.4 \mathrm{c}$ & $34.6 \mathrm{a}$ \\
\hline & PPr-Prod & $36.2 \mathrm{a}$ & $11.1 \mathrm{a}$ & $5.3 \mathrm{a}$ & $26.3 \mathrm{a}$ \\
\hline & LSD & 1.75 & 1.96 & 1.25 & 10.83 \\
\hline \multirow[t]{21}{*}{ Dates } & $1^{\text {st }}$ March & $5.3 \mathrm{jk}$ & $1.4 \mathrm{~h}$ & $0.6 \mathrm{j}-1$ & $4.0 \mathrm{~h}$ \\
\hline & $15^{\text {th }}$ March & $7.1 \mathrm{j}$ & $1.6 \mathrm{gh}$ & $0.8 \mathrm{j}-1$ & $4.9 \mathrm{gh}$ \\
\hline & $1^{\text {st }}$ April & $9.5 \mathrm{i}$ & $2.7 \mathrm{f}-\mathrm{h}$ & $1.1 \mathrm{i}-\mathrm{k}$ & $7.4 \mathrm{f}-\mathrm{h}$ \\
\hline & $15^{\text {th }}$ April & $14.6 \mathrm{~h}$ & $3.5 \mathrm{f}-\mathrm{h}$ & $1.8 \mathrm{i}-\mathrm{k}$ & $12.1 \mathrm{e}-\mathrm{h}$ \\
\hline & $1^{\text {st }}$ May & $20.2 \mathrm{~g}$ & $3.9 \mathrm{fg}$ & $1.3 \mathrm{i}-1$ & $19.6 \mathrm{~d}-\mathrm{f}$ \\
\hline & $15^{\text {th }}$ May & $27.2 \mathrm{e}$ & $7.7 \mathrm{~cd}$ & $3.3 \mathrm{e}-\mathrm{h}$ & $21.8 \mathrm{c}-\mathrm{e}$ \\
\hline & $1^{\text {st }}$ June & $29.4 \mathrm{~d}$ & $7.2 \mathrm{~cd}$ & $2.3 \mathrm{hi}$ & $25.2 \mathrm{~cd}$ \\
\hline & $15^{\text {th }}$ June & $31.9 \mathrm{c}$ & $8.1 \mathrm{~cd}$ & $3.9 \mathrm{c}-\mathrm{f}$ & $25.6 \mathrm{~cd}$ \\
\hline & $1^{\text {st }}$ July & $32.9 \mathrm{c}$ & $8.9 \mathrm{c}$ & $3.8 \mathrm{~d}-\mathrm{g}$ & $27.3 \mathrm{~b}-\mathrm{d}$ \\
\hline & $15^{\text {th }}$ July & $43.0 \mathrm{~b}$ & $11.6 \mathrm{~b}$ & $5.6 \mathrm{ab}$ & $26.8 \mathrm{~b}-\mathrm{d}$ \\
\hline & $1^{\text {st }}$ August & $50.1 \mathrm{a}$ & $13.5 \mathrm{~b}$ & $4.6 \mathrm{~b}-\mathrm{e}$ & $41.4 \mathrm{ab}$ \\
\hline & $15^{\text {th }}$ August & $51.5 \mathrm{a}$ & $16.7 \mathrm{a}$ & $6.3 \mathrm{a}$ & $38.9 \mathrm{ab}$ \\
\hline & $1^{\text {st }}$ September & $50.4 \mathrm{a}$ & $12.4 \mathrm{~b}$ & $5.3 \mathrm{a}-\mathrm{c}$ & $44.3 \mathrm{a}$ \\
\hline & $15^{\text {th }}$ September & $42.4 \mathrm{~b}$ & $11.4 \mathrm{~b}$ & $5.2 \mathrm{a}-\mathrm{d}$ & $34.0 \mathrm{a}-\mathrm{c}$ \\
\hline & $1^{\text {st }}$ October & $28.2 \mathrm{de}$ & $6.6 \mathrm{c}-\mathrm{e}$ & $2.4 \mathrm{~g}-\mathrm{i}$ & $25.8 \mathrm{~cd}$ \\
\hline & $15^{\text {th }}$ October & $22.8 \mathrm{f}$ & $6.3 \mathrm{de}$ & $2.5 \mathrm{f}-\mathrm{i}$ & $18.6 \mathrm{~d}-\mathrm{f}$ \\
\hline & $1^{\text {st }}$ November & $19.7 \mathrm{~g}$ & $4.6 \mathrm{ef}$ & $2.2 \mathrm{~h}-\mathrm{j}$ & $17.5 \mathrm{~d}-\mathrm{g}$ \\
\hline & $15^{\text {th }}$ November & $10.4 \mathrm{i}$ & $3.1 \mathrm{f}-\mathrm{h}$ & $1.1 \mathrm{i}-1$ & $8.6 \mathrm{f}-\mathrm{h}$ \\
\hline & $1^{\text {st }}$ December & $4.6 \mathrm{k}$ & $1.7 \mathrm{gh}$ & 0.31 & $3.0 \mathrm{~h}$ \\
\hline & $15^{\text {th }}$ December & $3.9 \mathrm{k}$ & $1.2 \mathrm{~h}$ & $0.4 \mathrm{kl}$ & $2.8 \mathrm{~h}$ \\
\hline & LSD & 2.1 & 2.312 & 1.480 & 12.80 \\
\hline \multirow[t]{3}{*}{ Year } & 2011 & 25.4 & 6.4 & 3.1 & 15.8 \\
\hline & 2012 & 25.1 & 7.0 & 2.4 & 25.2 \\
\hline & Significance & Ns & Ns & Ns & $\mathrm{Ns}$ \\
\hline Interaction & $A \times D$ & 0.00 & 0.00 & 0.00 & 0.00 \\
\hline
\end{tabular}

Number of Bactrocera zonata (Bitter gourd)

Statistical analysis of the data showed (Table 3) that different attractants significantly influenced number of $B$. zonata during both the years. Similarly different dates of trapping also considerably influenced $B$. zonata. Number of $B$. zonata did not influence by year. The interaction between attractants and trapping dates were also found significant. Mean value of the data indicated that higher number B. zonata was captured by PPr-Product trap (11.1) followed by M.E (8.3), whereas C.L traps trapped least number of M.E trap (0.8). the capturing of fruit flies were increased from $1^{\text {st }}$ March to $15^{\text {th }}$ August, after which it was in decline and hence the maximum number of $B$. zonata (16.7) were captured in mid August followed by $1^{\text {st }}$ August (13.5) which was at par with September, whereas the least number of $B$. zonata were trapped in early March (1.4) which was at par with the $B$. zonata captured in mid March, April and 
December, respectively. Interaction between attractants and dates of observation revealed that PPr-Product trapped more $B$. zonata than both imported traps i.e. C.L and M.E in the month of September (Fig.10)

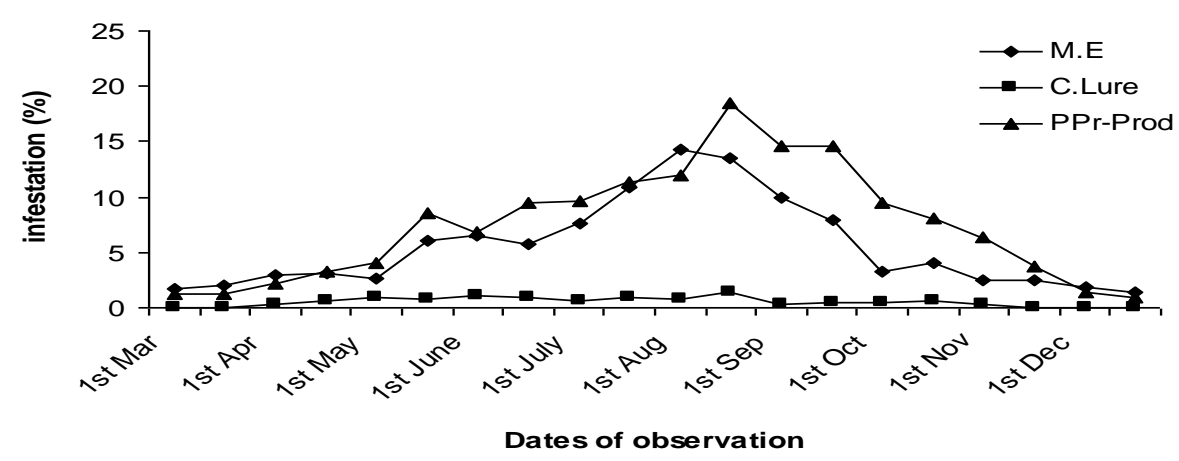

Figure 10. Interaction of attractant and dates for number Bactrocera zonata in bitter gourd at Charsada during 2010 and 2011 Number of Bactrocera dorsalis (Bitter gourd)

Data regarding number of $B$. dorsalis attracted to different attractants in Bitter gourd field in Charasada are shown in Table 3. Statistical analysis of the data showed that attractants were found significantly different in capturing $B$. dorsalis. Likewise number of $B$. dorsalis varied among different dates. Year as source of variance was found not significant. The interaction between attractants and dates were also found significant for number of $B$. dorsalis. Comparing attractants, it was found from the two year averaged data that PPr-Product resulted in higher capture of $B$. dorsalis (5.3) followed by M.E (2.6), whereas lower

number of $B$. dorsalis (0.4) was trapped in C. Lure traps. B. dorsalis were in abundantly increased from $1^{\text {st }}$ March to $15^{\text {th }}$ August, after which it was in decline and hence the highest number of $B$. dorsalis (6.3) captured in mid August, followed by $B$. dorsalis trapped in months of September and mid July whereas the least number of $B$. dorsalis were trapped in month of $1^{\text {st }}$ December which was similar to November, mid December and March. Interaction between attractants and dates of observation showed that more captured of $B$. dorsalis was made by PPr-Product in months of August and September as compared to Methyl Eugenol and C. L (Fig.11)

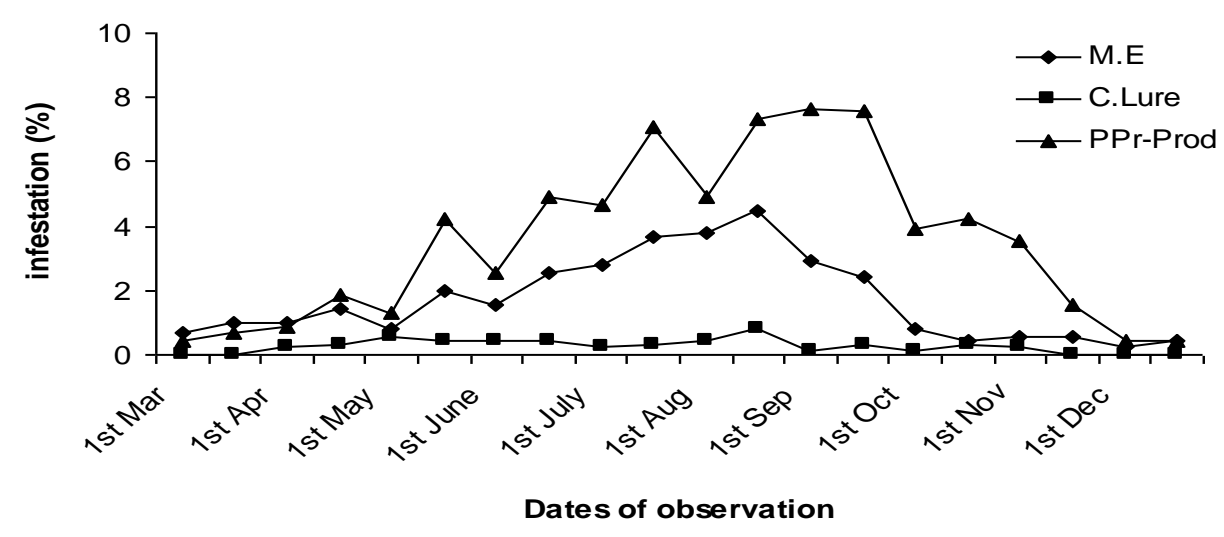

Figure 11. Interaction of attractant and dates for number Bactrocera dorsalis in bitter gourd at Charsada during 2010 and 2011 


\section{Number of Bactrocera cucuribitae (Bitter gourd)}

Data regarding the number of $B$. cucuribitae attracted to different attractants fruit flies in Bitter gourd, which were attracted by different attractants (M.E, C.L and PPrProduct) on different dates in Charasada shown in Table 3. Statistical analysis of the data showed that attractants were found significantly different in capturing $B$. cucuribitae. Likewise number of fruit flies varied among different dates. Year as source of variance was found not significant. The interaction between attractants and dates were also found significant for number of fruit flies. Comparing attractants, it was cleared from two year averaged data that C.L resulted in higher capture of $B$. cucuribitae (34.6) which was at par with PPr-Product (26.3), whereas lower number of $B$. cucuribitae (0.5) was captured in M.E traps. Trapping of fruit flies were increased from March to early September, after which it was in decline and hence the maximum number of $B$. cucuribitae (44.3) were trapped in early September which was similar to month of August and mid September whereas lower number of $B$. cucuribitae (2.8) were trapped in mid December which was similar to the flies captured in early December, March and month of April. Interaction between attractants and dates of observation indicated that more number of $B$. cucurbitae were captured by $\mathrm{C}$. L in month of July as compared to M. E (Fig.12).

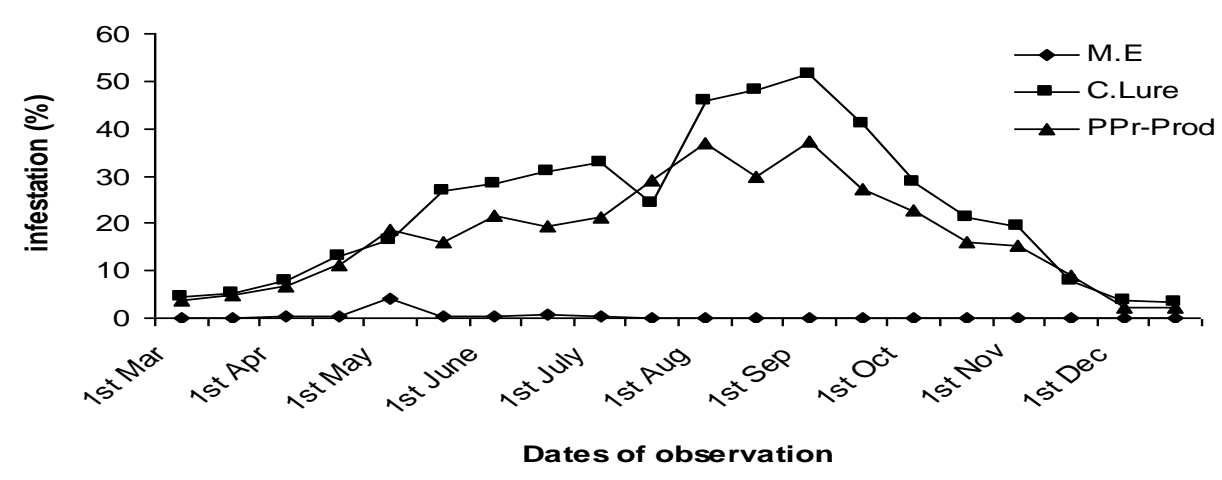

Figure. 12. Interaction of attractant and dates for number Bactrocera cucurbitae in bitter gourd at Charsada during 2010 and 2011

\section{Response of sexes against different attractants}

Response of sexes in bitter gourd against attractants

The obtained data indicated that all the three fruit fly species male and female adults have different degrees of prefer-ability for the different attractants in Bitter gourd orchards Table 4). The PPr-Product traps were found more effective for female against $B$. zonata
$(550 \pm 4.2), B$. dorsalis $(298 \pm 3.2)$ and $B$. cucurbitea $(1150 \pm 3.8)$ as compared to the imported traps M.E and C.L. In case of male adults, the effectiveness of M.E traps was greatest in $B$. zonata $(460 \pm 3.2)$ and $B$. dorsalis $(165 \pm 3.1)$ whereas C.L was found more effective against male adults of $B$. cucurbitae with capture of $1500 \pm 4.7$ as compared to local PPr-Product $(60 \pm 3.2)$ and M.E. $(43 \pm 2.2)$. 
Table 4. Mean $( \pm \mathrm{SE})$ captured $B$. zonata, B. dorsalis and $B$. cucurbitae females and males by different attractants on bitter gourd orchards at Charsada district (average of two years 2011-12)

\begin{tabular}{|l|l|l|l|l|l|l|}
\hline & B zonata & & B dorsalis & & B cucurbitae & \\
\hline Attractants & Male & Female & Male & Female & Male & Female \\
\hline M.E & $460 \pm 3.2$ & $3 \pm 1.1$ & $165 \pm 3.1$ & $2 \pm 0.2$ & $43 \pm 2.2$ & $2 \pm 0.1$ \\
\hline C.L & $75 \pm 1.3$ & $6 \pm 0.9$ & $35 \pm 1.5$ & $4 \pm 0.3$ & $1500 \pm 4.7$ & $90 \pm 2.1$ \\
\hline PPR Prod & $56 \pm 1.1$ & $550 \pm 4.2$ & $50 \pm 1.3$ & $298 \pm 3.2$ & $60 \pm 3.2$ & $1150 \pm 3.8$ \\
\hline
\end{tabular}

Response of male and female adults in guava orchards

The data regarding male and female adults of the three fruit fly species have different degrees of prefer-ability for different attractants in Guava orchards (Table 5). Mean values of the data indicated that The M.E traps were found more effective against male adults of $B$. zonata $(2110 \pm 13.2)$ and $B$. dorsalis $(6159 \pm 3.2)$ whereas C.L had the maximum capture of male adults in $B$. cucurbitae (525 \pm 4.2 ) as compared to PPrProduct and M.E. The highest capture of female adults of $B$. zonata $(603 \pm 4.2), B$. dorsalis $(440 \pm 5.2)$ and B. cucurbitae (346 \pm 3.2 ) were obtained by PPr-Product followed by M.E with capture of female adults in $B$. zonata $(3 \pm 1.1), B$. dorsalis $(8$ \pm 1.2 ) however the capture of $B$. cucurbitae was higher in C.L $(5 \pm 1.1)$ as compared to M.E which was found unable to capture even a single $B$. cucurbitae of both sexes.

Table 5. Mean ( \pm SE) captured B. zonata, B. dorsalis and B. cucurbitae females and males by different attractants on guava orchards at Kohat district (average of two years 2011-12)

\begin{tabular}{|l|l|l|l|l|l|l|}
\hline \multicolumn{2}{|c|}{ B. zonata } & & B. dorsalais & & B. cucurbitae & \\
\hline Attractants & Male & Female & Male & Female & Male & Female \\
\hline M.E & $2110 \pm 13.2$ & $3 \pm 1.1$ & $6159 \pm 3.2$ & $8 \pm 1.2$ & $0 \pm 0.0$ & $0 \pm 0.0$ \\
\hline C.L & $0 \pm 0.0$ & $0 \pm 0.0$ & $0 \pm 0.0$ & $0 \pm 0.0$ & $525 \pm 4.2$ & $5 \pm 1.1$ \\
\hline PPR Prod & $188 \pm 8.2$ & $603 \pm 4.2$ & $41 \pm 1.8$ & $440 \pm 5.2$ & $57 \pm 1.2$ & $346 \pm 3.2$ \\
\hline
\end{tabular}

Response of male and female adults in peach orchards

The data on the sexes of the three fruit fly species in peach orchards in Swat are reported in Table 6. Two year averaged data revealed that male and female adults were effectively captured by different attractants in Peach orchards. The male adults of $B$. zonata and $B$. dorsalis were more effectively captured by M.E $(1318 \pm 7.2$ and $460 \pm 5.2$, respectively) followed by PPr-Product whereas C.L traps could not capture any male adult of the both species, however more B. cucurbitae male adults (334 \pm 8.2$)$ were captured by C.L as compared to PPrProduct and M.E traps. The highest female adults of $B$. zonata $(890 \pm 4.2), B$. dorsalis $(236 \pm 4.0)$ and $B$. cucurbitae $(90 \pm 1.2)$ were captured by PPr-Product followed by M.E with capture of female adults in $B$. zonata $(6$ $\pm 1.2)$, B. dorsalis $(3 \pm 1.2)$ and B. cucurbitae $(8 \pm 0.9)$ as compared to C.L which cound not been able to capture even a single female adults of the three species. 
Table 6. Mean $( \pm \mathrm{SE})$ captured $B$. zonata, $B$. dorsalis and $B$. cucurbitae females and males by different attractants on peach orchards at Swat district (average of two years 2011-12)

\begin{tabular}{|c|c|c|c|c|c|c|}
\hline & B. zonata & & B. dorsalais & & B. cucurbitae & \\
\hline Attractants & Male & Female & Male & female & Male & Female \\
\hline M.e & $1318 \pm 7.2$ & $6 \pm 1.2$ & $460 \pm 5.2$ & $3 \pm 1.2$ & $12 \pm 0.7$ & $8 \pm 0.9$ \\
\hline C.L & $0 \pm 0.00$ & $0 \pm 0.0$ & $0 \pm 0.0$ & $0 \pm 0.0$ & $334 \pm 8.2$ & $3 \pm 0.7$ \\
\hline PPR Prod & $39 \pm 3.2$ & $890 \pm 4.2$ & $24 \pm 3.0$ & $236 \pm 4.0$ & $13 \pm 1.2$ & $90 \pm 1.2$ \\
\hline
\end{tabular}

\section{Discussion}

Results shows that significant variation was recorded for the captured of fruit flies among different attractants and observational dates in guava, peach and bitter gourd orchards. More number of fruit flies in Guava orchards captured by imported trap i.e. Methyl Eugenol (M.E) which was followed by the local Plant Protection Product (PPr) whereas lesser number of fruit flies were trapped by the imported Cue lure. The probable reason for more capture of fruit flies by M.E might be due to the facts that M.E had higher potency for $B$. zonata which were abundant in the overall population as compared to C.L traps. High potency of local product capturing both sexes of fruit flies was because of its palatable food which ultimately become more effective in capturing overall fruit fly species as compared to C.L. The results obtained here are thus very encouraging in the search of a new local attractant for both male and female flies which can be easily accessible to the farmers.

Higher capture of $B$. zonata and B. dorsalis in Guava was recorded by Methyl Eugenol followed by PPr-Product, whereas C.L was unable to trap even single specie of $B$. zonata and $B$. dorsalis on other hand Cue lure attracted more $B$. cucuribitae followed by PPr-Product but ME failed to attract $B$. cucuribitae under same conditions. The results are in line with Maquate et al [16] who stated that fruit fly species, such as $B$. dorsalis and $B$. cucurbitae were effectively attractive to methyl eugenol and cue lure, respectively.
Number of $B$. zonata increased from $1^{\text {st }}$ march to end of June where the number of Bactrocera were in its peak from July to mid of December its population was decreased drastically. Higher fruit fly was recorded in mid and early September whereas lesser fruit fly was recorded in mid December which was at par with both early December and March. The fruit flies larvae feed on the pulp of ripe fruits forming tunnels inside them causing a great damage and make fruits unfavorable [1, 17]. According to Maquate\& Peck [16] Syed et al., [18] and Pena[19]B. zonata causing a significant damage in number of fruit species. These findings provide evidence for the distinct peaks and mild activity as observed in the present study. Furthermore, many other workers also reported peak activity of $B$. cucurbitae during different months of the year when the prevalent climatic conditions were favorable. These peaks were from April to July Kawashita, et al., [20] and midJune to mid-November [21-23]. The peak activity occurred from the second fortnight of April to November. In a field study, similar results were obtained and observed the inactive period of $B$. cucurbitae to be from January to March by [24- 26]. The capture of B. cucuribitae was increased from March to mid July and then it was declined from July to December. Higher $B$. cucuribitae were trapped in early July followed by mid July whereas lesser number of B. cucuribitae was trapped in March and December. The fruit flies captured enhanced from march to end of June and after it drastically reduced till mid of December and 
hence higher number of $B$. dorsalis were trapped in July followed by mid June, whereas its capture lowered in months of March, November and December.

Like Guava orchards, in case of peach orchards at swat district, the M.E trapped more fruit flies followed by PPR-product whereas lesser fruit flies were captured by C.L. Higher number of $B$. zonata and $B$. dorsalis was trapped by Methyl Eugenol followed by PPr-Product, whereas B. zonata and $B$. dorsalis were not captured /attracted by Cue lure under same orchard. In case of B. cucuribitae, M.E was the lowered in capture followed by PPr-Product where C.L captured higher number of $B$. cucuribitae in peach orchards. Possible reason for higher traps of fruit flies species in $\mathrm{ME}$ in comparison with C.lue and PPr-Prod. may be least prevalence of species and their preference towards attractants. Overall our result are in line with Ukey [27] who found that higher number of were trapped in $\mathrm{ME}$ compared to C-lure.

The overall fruit fly populations in peach orchards were on peaks in mid and early September whereas its population reached to minimum from middle of December to March. Populations of $B$. zonata were higher in October to mid-December after that the population decreased drastically and thus lesser $B$. zonata were recorded in those months.

For Bitter gourd experiment conducted at Charsada district, finding of the study revealed that higher number of fruit flies was captured by PPr-Product as compared to both C.L and M.E traps. Likewise, more number of $B$. zonata captured by PPrProduct followed by M.E, whereas C.L trapped least number of $B$. zonata. PPrProduct captured higher number of $B$. dorsalis followed by M.E whereas lower number of $B$. dorsalis was recorded in $C$. Lure traps. C.L resulted in higher capture of B. cucuribitae followed by PPr-Product, whereas lower number of $B$. cucuribitae was recorded in M.E traps. The capturing of fruit flies were increased from March to $15^{\text {th }}$ September and after it decline till mid of December. The number of B. cucuribitae trapped was increased from March to mid September and then declined from $1^{\text {st }}$ October till the end of December. PPrProduct attracted more fruit flies followed by Cue lure whereas Methyl Eugenol attracted lesser fruit flies. According to Ghanim [16], Pena et al. [19] Syed et al. [18] B. zonata causing a considerable damage in many fruit species. More number of $B$. zonata was captured by PPr-Product trap followed by M.E, whereas lower number of fruit flies was captured by $\mathrm{C}$. Lure traps. The results are in line with findings of other researchers and the presumed role played by protein baits in shape of local product as a food attractants and sources, in particular to immature females [6].

The capture of fruit flies increased from March to $15^{\text {th }}$ August; thereafter it was decline till mid December. The capture of fruit flies increased from $1^{\text {st }}$ March to $15^{\text {th }}$ August, after which it was decline till $15^{\text {th }}$ December. C.L resulted in higher capture of fruit flies followed by PPr-Product, whereas lower number of fruit flies was recorded in M.E traps. Trapping of fruit flies increased from March to end of August, after which its population decreased.

All the three fruit fly species male and female adults have different degrees of preference for the different attractants in Bitter gourd orchards. The PPr product was found more effective against $B$. zonata, $B$. dorsalis and B. cucurbitae as compared to the imported luresf i.e. M.E and C.L. In case of male adults, the effectiveness of M.E traps was greatest in $B$. zonata and $B$. dorsalis whereas C.L was found more effective against male adults of $B$. 
cucurbitae as compared to PPr-Product and M.E.

The M.E traps were found more effective against male adults of $B$. zonata and $B$. dorsalis whereas C.L had the maximum capture of male adults in B. cucurbitae as compared to PPr-Product and M.E. The highest capture of female adults of $B$. zonata, B. dorsalis and B. cucurbitae were obtained by PPr-Product followed by M.E with capture of female adults in B. zonata, $B$. dorsalis, however the capture of $B$. cucurbitae was higher in C.L as compared to M.E which was found unable to capture even a single $B$. cucurbitae of both sexes.

The male adults of $B$. zonata and $B$. dorsalis were more effectively captured by M.E followed by PPr-Product whereas C.L traps could not capture any male adult of both the species, however more $B$. cucurbitae male adults were captured by C.L as compared to PPr-Product and M.E traps. The highest female adults of $B$. zonata, B. dorsalis and B. cucurbitae were captured by PPr-Product followed by M.E with capture of female adults in $B$. zonata, $B$. dorsalis and $B$. cucurbitae as compared to C.L which could not been able to capture even a single female adults of the three species. Female of the fruit flies are attracted to protein source for their body development particularly virgin females and therefore it was used as bait or food attractants. Female required protein for the development of eggs than male [28]. These findings are in line with the findings of Liu [21] who stated that adult female tephritids fruit flies were effectively attracted to protein bait and male to Methyl eugenol and Cue lure.

\section{Conclusion}

It was concluded from this study that the PPr-Product was found more effective against all three types of female adults flies whereas M.E traps captured more $B$. zonata and $B$. dorsalis while Cue Lure captured more male adults of $B$. cucurbitae in peach, bitter gourd and guava orchards. The highest capture of female adults of the three species was obtained by PPr-Product in guava and peach orchards. So, among these three attractants the PPr-Product attracted more number of female of all the three species in all orchards.

\section{Authors' contributions}

Conceived and designed the experiments: MQ Kakar \& F Ullah, Performed the experiments: MQ Kakar \& H Zada, Analyzed the data A Shah \& T Iqbal, Contributed reagents/ materials/ analysis tools: S Ahmad \& B Ahmad, Wrote the paper MQ Kakar.

\section{References}

1. White I \& Elson-Harris MM (1994). Fruit Flies of Economic Significance: Their Identification and Bionomics. CAB International with ACIAR. P. 601.

2. Mun JH, Bohonak AJ \& Roderick GK (2003). Population structure of the pumpkin fruit fly Bactrocera depressa (Tephritidae) in Korea and Japan: Pliocene allopatry or recent invasion? Mol Ecol. 12:2941-51.

3. Permalloo S, Seewooruthun SI, Joomaye A, Soonnoo AR, Gungah B, Unmole L \& Boodram R (1998). An area wide control of fruit flies in Mauritius. In Proceedings of the 2 nd Annual Meeting of Agricultural Scientists, Food and Agricultural Research Council (pp. 203210).

4. Stonehouse JM, Mumford JD, \& Mustafa G (1998). Economic losses to tephritid fruit flies in Pakistan. Crop Prot.17: 159164.

5. Kafi A (1986). Progress and problems in controlling fruit flies infestation. Paper presented at FAO, RAPA, Bangkock, 1619 December, 1986.

6. Allwood J (1997). Control Strategies for Fruit Flies (Family Tephritidae) in the South Pacific. P.171-178.

7. Kapoor VC (1993). Indian fruit flies 
(Insccta: Diptera: Tephritidae).Oxford and IBH Pub Co Pvt, India, 228.

8. Vijasegaran S (1991). The current situation on fruit flies in peninsular Malaysia. In: Vijasegaran S and Ibrahim, AG, eds. First International Symposium on Fruit flies in the Tropics, Kuala Lumpur, Malaysia, March, 1988. 125139.

9. Troetschler RG (1983). Effects on non target arthropods of malathion bait sprays used in California to eradicate Mediterranean fruit fly, Ceratitis capitata. Environmental Entomol. 12: 1816-1822.

10. Emden HF van \& DB Peakall (1996). Beyond Silent Spring. Chapman and Hall, New York. (FAO) Food and Agricultural Organization of the United Nations, 1998. Agricultural statistics. http: www.Fao.org.

11. Jang EB \& Light DM (1996). Fruit Fly Pests, a World Assessment of their Biology and Management. Olfactory semio chemicals of trephritids, in BA McPheron and GJ Steck (eds), St Lucie Press, Delray Beach, FL. pp. 73-90.

12. Jang EB, Lori A, Carvalho A \& Stark J D (1997). Attraction of female Oriental fruit fly, Bactrocera dorsalis, to volatile semiochemicals form leaves and extracts of non host plant, Panax (Polyscias guilfoylei) in laboratory and olfactometer assays. J Chemical Eco. 23 (5): 1389-1401

13. Mehmood, K. \& Mishkatullah (2007). Population dynamics of three species of genus Bactrocera (Diptera: Tephritidae: Dacinae) in BARI Chakwal (Punjab). Pak J Zool. 39 (2): 123-127.

14. Drew RAI (1989). The tropical fruit flies (Diptera: Tephritidae: Dacinae) of the Australasian and Oceanian region. Memoirs of the Queensland Museum 26. South Brisbane, Australia.
15. Jan MT, Shah P, Hollington PA, Khan MJ \& Sohail Q (2009). Agriculture Research: Design and Analysis, A Monograph. NWFP Agricultural University Peshawar, Pakistan

16. Mcquate GT \& Peck SL (2001). Enhancement of attraction of alphaionol to male Bactrocera latifrons (Diptera: Tephritidae) by addition of a synergist, cade-oil. J Econ Entomol. 94:39-46.

17. White I \& Elson-Harris MM (1994). Fruit Flies of Economic Significance: Their Identification and Bionomics. CAB International with ACIAR. P. 601.

18. Syed RA, Ghani MA \& Murtaza M (1970). Studies on the tephritids and their natural enemies in West Pakistan. III. Dacus zonatus (Saunders) (Diptera: Tephritidae). Tech Bull Comm Wel Inst Biol Cont. 13: 1-6.

19. Pena JE, Mohyuddin AI \& Wysoki M (1998). A Review of the Pest Management Situation in Mango Agroecosystems Phyto parasitica 26(2):1-20.

20. Kawashita T, Rajapakse GBJP \& Tsuruta K (2004). Population surveys of Bactrocera fruit flies by lure trap in Sri Lanka. Research Bulletin of the Plant Protection Service, Japan. 40: 83-87.

21. Liu YC \& Lin JS (1993). The response of melon fly, Dacus cucurbitae Coq. to the attraction of $10 \%$ MC. Plant Prot. Bul. 35: 79-88.

22. Ramsamy MP, Rawanansham $\mathrm{T} \&$ Joomaye (1987). Studies on the control of Dacus cucurbitae Coq. and Dacus demmerezi Bezze (Diptera: Tephritidae) by male annihilation. Reve Agricole et the Mauriee. 66: 1-3.

23. Zaman M (1995). Assessment of the male population of fruit flies through kairomone baited traps and the association of the abundance level with the environmental factors. Sahad $J$ 
Agric. 11: 657-670.

24. Khan MA, Ashfaq M \& Khaliq A (2003). Population of fruit fly species trapped by methyl euginol and cue lure versus infestation in guava orchards. Pak Entomoligist. 25(1): 63-67.

25. Khattak SU, Afsar K, Hussain N, Khalil SK, \& Alamzeb. (1990). Annual population incidence of Oriental fruit fly (Dacus dorsalis Hendel) in a fruit orchard at Peshwar, Pakistan. Bangladesh J Zool. 18:131-138.

26. Lee LWY, Hwang YB, Cheng CC \& Chang JC (1992). Population fluctuation of the melon fly, Dacus cucurbitae in North- Eastern Taiwan. Chinese J Entomol. 12: 285-292.

27. Ukey NS, Chandele AG, Wagh SS \& Bansode GM (2013). Species composition of fruit flies, Bactrocera spp.(Diptera: Tephritidae) infesting guava in Maharashrtra. Pest Management In Horticultural Ecosystems. 19(2): 242-244.

28. Christenson LE \& Foote RE (1960). Biology of fruit flies. Ann Rev Entomol 5: 171-192. 